\title{
Surgical Service Key Performance Indicators for the Arctic Regions of Russia
}

\author{
Nikolay M. Gogolev, $\mathrm{PhD}^{1}$; Mikhail M. Vinokurov, $\mathrm{PhD}, \mathrm{ScD}^{1}$; \\ Tatyana E. Burtseva, PhD, ScD ${ }^{1,2^{*}}$; Maya P. Slobodchikova ${ }^{3}$ \\ ${ }^{1}$ Medical institute of M.K. Ammosov North-Eastern Federal University, Yakutsk, Russia \\ ${ }^{2} Y a k u t$ Science Center of Complex Medical Problems, Yakutsk, Russia \\ ${ }^{3}$ Saint Petersburg State Pediatric Medical University, Saint Petersburg, Russia
}

\begin{abstract}
The article represents surgical service key performance indicators (KPIs) in the Republic of Sakha (Yakutia) (RS(Y)) for the period between 2014 and 2016. According to the official statistics, the Arctic regions of RS(Y) are surgically understaffed, though formally there is high demand for medical staff and beds in surgery. The understaffing is due to peculiarities of RS(Y) its vast territory, low occupancy rate, the presence of sparsely populated territories and seasonal isolation of the population.(International Journal of Biomedicine. 2019;9(4):334-337.)
\end{abstract}

Key Words: surgical service $\bullet$ key performance indicators $\bullet$ staffing $\bullet$ air medical service $\bullet$ Yakutia

\section{Introduction}

The regions of Russia differ in the availability of medical services and medical staffing, the level of life, and development of transport and communication. A considerable part of normative legal documentation in the field of healthcare does not take into account specific characteristics of vast territories, the regions of the Far North in particular. RS(Y) is not an exception. Implementing the principles of healthcare organization and improving the availability of surgical services, including high tech medical services, are some of the priority tasks for the modern healthcare system. It should also be noted that federal and regional health care institutions have incomparably different capabilities to render surgical aid. ${ }^{(1-4)}$

The historical background of the lifestyle in $\mathrm{RS}(\mathrm{Y})$ has been defined by the presence of a great number of sparsely populated villages far from administrative centers and medical healthcare centers. These conditions have led to the creation of a very specific life-support system for the local population.

*Corresponding author: Tatiana E. Burtseva, PhD, ScD. M.K. Ammosov North-Eastern Federal University, Yakutsk, the Republic of Sakha (Yakutia), the Russian Federation.E-mail: bourtsevat@, yandex.ru
There are available, but incomplete, medical and preventive healthcare institutions for the local population, a high demand for specialized and air medical emergency service, as well as specialized exit medical aid. ${ }^{(1,5,6)}$ These peculiarities demand development and implementation of differentiated regional mechanisms in the state healthcare policy in the regions of the Far North of the Russian Federation (RF).

\section{Materials and Methods}

The evaluation of surgical service KPIs in RS(Y) is represented for the period of 2014-2016. We analyzed the provision of surgical service and staffing, availability of hospital beds, and air medical service calls in cases of surgical pathology.

\section{Results}

Yakutia (the Sakha Republic) is the largest subject $\left(3103.2 \mathrm{~km}^{2}\right)$ of the Russian Federation. It is one of the coldest regions in the world. In 2010, Yakutia had a population of 958,500 people; the population density of the Republic was 0.31 persons per $1 \mathrm{~km}^{2}$, while in a number of the Arctic regions, it ranged from 0.1 to 0.01 persons per $1 \mathrm{~km}^{2}$. About $40 \%$ of 
the territory lies above the Arctic Circle, where only $7 \%$ of the population lives, including the indigenous peoples of the North who lead a traditional nomadic way of life. All these factors have a certain impact on the medical aid organization for the population.

Ethnically, it is represented by the Yakuts (49.9\%), the Russians (37.8\%), the Ukrainians (2.2\%), the Evenks (2.2\%), the Evens (1.6\%), and other ethnicities (6.3\%). Currently, Yakutia consists of 35 administrative regions located in different climate zones, having different social and economic backgrounds, with an uncommon and differing network of medical and preventive healthcare institutions.

More than ninety percent of the Republic's territory is in the area of seasonal transport service, where communication is mainly by air, water and road (seasonal). About $76 \%$ of 34 districts do not have reliable transport links with the center of the Republic and surrounding regions. The most remote village is situated at a distance of $3,189 \mathrm{~km}$ from Yakutsk, and in the interior, the distance from the medical centers to the Central District Hospital averages about $400 \mathrm{~km}$ and yeararound travel is not possible. Difficulties in healthcare service organization, determined by the low density of population and underdevelopment of transport infrastructure in the Far North, cause high demands for all kinds of resources.

The level of surgical service provision tended to decrease from 2014 to 2016 , from $74 \%$ to $73.2 \%$ (Table 1). The level of paramedical personnel also tended to decrease, from $83.1 \%$ to $80.7 \%$. However, the medical staffing in RS(Y) is higher in comparison to the situation in the RF as a whole: 48 per 10,000 population in $2014,48.5$ per 10,000 population in 2015 , and 48.1 per 10,000 population in 2016 . The surgical service provision also tended to increase: 2.0 per 10,000 population in 2014 and 2.2 per 10000 population in 2016 . Provision of paramedical personnel is also higher than in the RF (115.1 per 10000 population in 2014, 113.3 in 2015, and 112.7 in 2016) (Table 1).

Table 1.

The level of medical and paramedical provision in RS(Y) from 2014 to 2016 (per 10,000 population)

\begin{tabular}{|l|c|c|c|c|}
\hline \multicolumn{1}{|c|}{ Indicators } & 2014 & 2015 & 2016 & The RF \\
\hline Medical staffing & 6186.25 & 6259 & 6310.5 & \\
\hline Individuals & 4580 & 4637 & 4617 & 543.6 thousand \\
\hline Staffing, \% & 74.0 & 74.1 & 73.2 & \\
\hline physician staffing & 48.0 & 48.5 & 48.1 & 37.2 \\
\hline Surgical staffing & 2.0 & 2.0 & 2.2 & \\
\hline Paramedical staffing & 13234.25 & 13300.25 & 13409.5 & \\
\hline Individuals & 10994 & 10844 & 10816 & 1309.8 thousand \\
\hline Staffing, \% & 83.1 & 81.5 & 80.7 & \\
\hline Nurse staffing & 115.1 & 113.3 & 112.7 & 89.6 \\
\hline
\end{tabular}

The provision of hospital beds per 10,000 individuals is decreasing considerably; thus, it was 107.0 in 2014 and dropped to 98.2 in 2016 . Nevertheless, the indicator is higher than in the RF in whole (Table 2).

Table 2.

The provision of hospital beds in RS(Y) from 2014 to 2016 (per 10,000 population)

\begin{tabular}{|l|c|c|c|c|}
\hline \multicolumn{1}{|c|}{ Indicators } & 2014 & 2015 & 2016 & The RF \\
\hline $\begin{array}{l}\text { Average number of beds } \\
\text { occupied per day (including } \\
\text { beds for fee) }\end{array}$ & 10214 & 10186 & 9425 & $\begin{array}{c}1097.1 \\
\text { thousand }\end{array}$ \\
\hline $\begin{array}{l}\text { Hospital bed provision per } \\
\text { 10,000 patients }\end{array}$ & 107.0 & 106.4 & 98.2 & 75.0 \\
\hline Bed occupancy & 314 & 322 & 323 & 319 \\
\hline Bed turnover & 25 & 27 & 28 & 27.9 \\
\hline Hospital bed per 1 person & 3.332 & 3.290 & 3.104 & \\
\hline Admission rate per 100 patients & 26,8 & 27,3 & 26,4 & \\
\hline Average hospital stay & 12.5 & 12.0 & 11.7 & 11.4 \\
\hline Inpatient mortality rate & 0.7 & 0.7 & 0.8 & 1.71 \\
\hline
\end{tabular}

By the end of 2016, there were 1,314 surgical beds; more of them ( 636 beds) were surgical beds for adults: 251 were traumatology beds for adults, 72 were neurosurgical ones (Table 3). Historically, the structure of hospital bed supply was established according to the needs of the local population. On the whole, inpatient mortality rate in surgical beds of $\mathrm{RS}(\mathrm{Y})$ was 0.9 by the end of 2016. There was the highest hospital mortality rate in neurosurgical and proctological beds (2.4 and 2.3 respectively).

Thus, the statistics confirm the common data that the regions of the Far North are better provided with hospital beds and medical staff per 10,000 patients than in the RF as a whole..$^{(7)}$ It is certainly well grounded that these are the regions of the Far North that have difficult transport infrastructure, seasonal isolation of the population and severe natural and climate conditions for living. All these conditions predispose the region toward upkeep of networks of medical and healthcare institutions in each populated area.

The surgical staff requirement confirms the indicator that the regions of the Republic are well provided. The most understaffed regions are Abyysky, Allaikhovsky, Bulunsky, Verkhoyansky, Kobiaysky, Ust-Maysky, Ust-Yansky, and Verkhne-Kolymsky. The surgeons are required each year. It should be noted that the most problematic regions are the Arctic regions of the Republic, i.e. Abyyskiy, Allaikhovsky and Bulunsky districts. The indicator there reaches up to $50 \%$ of staff provision (Table 4).

As $\mathrm{RS}(\mathrm{Y})$ is a vast territory, in emergency cases the air medical service is required. Annual calls for air medical service vary; however, the data per 1000 patients are rather stable, 1.6 in 2014 and 1.6 in 2016 (Table 5).

As described in Table 6, the air medical service calls for surgical treatment were almost two times more in the period of 1993-1995. The number of planned and emergency operations was also two times more. The dynamics of 2013-2015 is rather stable in the number of air service calls and planned/ emergency operations. 
Table 3.

\section{Surgical beds profile in $R S(Y)$}

\begin{tabular}{|c|c|c|c|c|c|c|c|}
\hline $\begin{array}{l}\text { Hospital bed } \\
\text { profile }\end{array}$ & $\begin{array}{c}\text { Number } \\
\text { of beds by } \\
31.12 .16\end{array}$ & $\begin{array}{c}\text { Admission } \\
\text { rate per } \\
1000 \\
\text { individuals }\end{array}$ & AHS & $\begin{array}{l}\text { Hospital } \\
\text { bed per } \\
1 \text { person }\end{array}$ & $\begin{array}{c}\text { AHS } \\
\text { per year }\end{array}$ & Turn- & IMR \\
\hline $\begin{array}{l}\text { Surgical } \\
\text { profile, } \\
\text { total }\end{array}$ & 1314 & 41.8 & 10.5 & 0.440 & 324 & 31 & 0.9 \\
\hline $\begin{array}{l}\text { Among them: } \\
\text { adult surgery }\end{array}$ & 636 & 30 & 10 & 0.299 & 330 & 33 & 1.3 \\
\hline $\begin{array}{l}\text { pediatric } \\
\text { surgery }\end{array}$ & 21 & 3.2 & 8.1 & 0.026 & 322 & 40 & 0.7 \\
\hline \begin{tabular}{|l|} 
adult \\
neurosurgery
\end{tabular} & 72 & 2.4 & 13.4 & 0.033 & 318 & 24 & 2.4 \\
\hline $\begin{array}{l}\text { pediatric } \\
\text { neurosurgery }\end{array}$ & 15 & 1.3 & 13.1 & 0.017 & 295 & 22 & 0.3 \\
\hline $\begin{array}{l}\text { cardiac } \\
\text { surgery }\end{array}$ & 33 & 1.2 & 10.5 & 0.013 & 306 & 29 & 1.2 \\
\hline $\begin{array}{l}\text { vascular } \\
\text { surgery }\end{array}$ & 32 & 1.8 & 7.5 & 0.013 & 318 & 42 & 0.1 \\
\hline \begin{tabular}{|l} 
adult \\
traumatology
\end{tabular} & 251 & 8.9 & 12.5 & 0.112 & 315 & 25 & 0.6 \\
\hline \begin{tabular}{|l|} 
pediatric \\
traumatology
\end{tabular} & 30 & 4.4 & 10.6 & 0.047 & 407 & 38 & 0 \\
\hline burn & 50 & 0.9 & 18 & 0.016 & 304 & 17 & 1.2 \\
\hline $\begin{array}{l}\text { adult } \\
\text { urological }\end{array}$ & 43 & 1.8 & 9.6 & 0.017 & 309 & 32 & 0.2 \\
\hline $\begin{array}{l}\text { pediatric } \\
\text { urological }\end{array}$ & 20 & 3.2 & 8 & 0.025 & 331 & 41 & 0 \\
\hline proctological & 25 & 0.9 & 10.2 & 0.009 & 363 & 35 & 2.3 \\
\hline $\begin{array}{l}\text { pediatric } \\
\text { contaminated } \\
\text { surgery }\end{array}$ & 20 & 2.4 & 10.6 & 0.025 & 330 & 46 & 0 \\
\hline $\begin{array}{l}\text { maxillofacial } \\
\text { surgery }\end{array}$ & 30 & 2 & 7.1 & 0.014 & 330 & 46 & 0 \\
\hline $\begin{array}{l}\text { pediatric } \\
\text { maxillofacial } \\
\text { surgery }\end{array}$ & 10 & 0.9 & 6.6 & 0.006 & 147 & 22 & 0 \\
\hline $\begin{array}{l}\text { pediatric } \\
\text { dental } \\
\text { surgery }\end{array}$ & & & & & & & \\
\hline $\begin{array}{l}\text { adult } \\
\text { orthopedic }\end{array}$ & 26 & 1.2 & 10.3 & 0.012 & 329 & 32 & 0 \\
\hline
\end{tabular}

AHS - Average hospitalstay; IMR - Inpatient mortality rate

Table 5.

The air medical service calls in RS(Y) from 2014 to 2016

\begin{tabular}{|l|c|c|c|}
\hline \multicolumn{1}{|c|}{ Indicators } & 2014 & 2015 & 2016 \\
\hline Numbers of calls & 1497 & 1460 & 1580 \\
\hline Per 1,000 patients & 1,6 & 1,5 & 1,6 \\
\hline
\end{tabular}

\section{Table 6.}

The air medical service calls for surgical treatment in $R S(Y)$

\begin{tabular}{|l|c|c|c|c|c|c|c|}
\hline \multicolumn{1}{|c|}{ Indicators } & 1993 & 1994 & 1995 & & 2013 & 2014 & 2015 \\
\hline Number of calls & 3953 & 3331 & 2986 & & 1594 & 1547 & 1632 \\
\hline Operations & $\ldots$ & 1011 & 787 & & 418 & 389 & 368 \\
\hline
\end{tabular}

Table 4.

The surgical staff provision in RS(Y) from 2014 to 2016 (per 10,000 population)

\begin{tabular}{|c|c|c|c|}
\hline \multirow{2}{*}{ Districts } & \multicolumn{3}{|c|}{ Surgical staff provision } \\
\hline & 2014 & 2015 & 2016 \\
\hline Abyysky & 50.0 & 50.0 & 50.0 \\
\hline Adlansky & 85.7 & 69.6 & 69.6 \\
\hline Allaikhovsky & 50.0 & 50.0 & 100.0 \\
\hline Amginsky & 100.0 & 66.7 & 66.7 \\
\hline Anabarsky & 200.0 & 100.0 & 100.0 \\
\hline Bulunsky & 44.4 & 44.4 & 47.1 \\
\hline Verkhne-Viluysky & 133.3 & 133.3 & 133.3 \\
\hline Verkhne-Kolymsky & 100.0 & 100.0 & 50.0 \\
\hline Verkhoyansky & 85.7 & 85.7 & 33.3 \\
\hline Viluysky & 88.9 & 94.1 & 100.0 \\
\hline Gorniy & 171.4 & 240.0 & 80.0 \\
\hline Zhigansky & 50.0 & 100.0 & 100.0 \\
\hline Kobiaysky & 94.1 & 94.1 & 57.1 \\
\hline Lensky & 52.6 & 55.6 & 64.9 \\
\hline Megino-Kangalassky & 83.3 & 96.0 & 96.0 \\
\hline Mirninsky & 83.9 & 90.3 & 82.5 \\
\hline Momsky & 100.0 & 100.0 & 100.0 \\
\hline Namsky & 120.0 & 120.0 & 44.4 \\
\hline Nerungrinsky & 58.0 & 65.7 & 67.7 \\
\hline Nizhnekolymsky & 100.0 & 80.0 & 66.7 \\
\hline Nyurbinsky & 75.0 & 100.0 & 100.0 \\
\hline Oimiakonsky & 42.9 & 28.6 & 100.0 \\
\hline Olyokminsky & 75.0 & 75.0 & 75.0 \\
\hline Oleneksky & 100.0 & 100.0 & 100.0 \\
\hline Srednekolimsky & 100.0 & 66.7 & 100.0 \\
\hline Suntarsky & 100.0 & 100.0 & 100.0 \\
\hline Tattinsky & 100.0 & 100.0 & 50.0 \\
\hline Tomponsky & 88.9 & 88.9 & 88.9 \\
\hline Ust-Adansky & 133.3 & 100.0 & 100.0 \\
\hline Ust-Maysky & 70.6 & 70.6 & 53.3 \\
\hline Ust-Yansky & 50.0 & 33.3 & 66.7 \\
\hline Khangalassky & 85.7 & 83.3 & 83.3 \\
\hline Churapchinsky & 142.9 & 100.0 & 100.0 \\
\hline Eveno-Bytantaicky & 100.0 & 100.0 & 100.0 \\
\hline $\begin{array}{l}\text { Healthcare } \\
\text { Committee, Yakutsk }\end{array}$ & 82.9 & 81.0 & 66.7 \\
\hline $\begin{array}{l}\text { Republican } \\
\text { institutions }\end{array}$ & 96.2 & 64.3 & 66.1 \\
\hline $\mathrm{RS}(\mathrm{Y})$, total & 85.3 & 75.4 & 73.2 \\
\hline
\end{tabular}

\section{Conclusion}

The analysis of surgical service KPIs for RS(Y) has definitely described high demand for surgical specialists in the regions of the Far North. The situation will increase 
prospectively more as surgical technologies are developed. Besides that, the building of a new oncologic dispensary is planned. RS(Y) has preserved the existing medical staff of surgeons, thus it has increased the number of staff to develop and implement new high-tech methods of treatment. Moreover, it has preserved the medical staff of surgeons in all central regional hospitals, even in the Arctic regions where the density of population is extremely low.

\section{Competing Interests}

The authors declare that they have no competing interests.

\section{Sources of Funding}

The reported study was funded by RFBR according to the research project \#18-05-60035_Arctica.

\section{References}

1. Andreev BV, Argunov S, Savinov DL. [Some aspects of emergency medical care in uluses of the Republic of Sakha (Yakutia) by the center of disaster medicine]. Materials of the Republican scientific and practical conference «Actual problems of emergency medical care». Yakutsk, 2000;1:9-12. [Article in Russian].

2. Vodnenko IM. [Actual problems of reforming of rural public health]. Problemy Sotsialnoi Gigieny, Zdravookhraneniya, i Istorii Meditsiny. 2000;4:26-28. [Article in Russian].

3. Vodnenko IM, Polyakov IV, Sergeev IP, Zelenskaya TM, Pascal AV. [Actual problems of the organization of specialized medical aid for the villagers]. Problemy Sotsialnoi Gigieny, Zdravookhraneniya, i Istorii Meditsiny. 2002;2:35-36. [Article in Russian].

4. Dominov IS, Kapitonov VF, Wagner VA, Galichev GA. [Approaches to primary health care reform in rural areas of Siberia]. Problemy Sotsialnoi Gigieny, Zdravookhraneniya, i Istorii Meditsiny. 2007;2:35-37. [Article in Russian].

5. Alexandrov VL. [On the state and prospects of the development of emergency medical care in the Republic of Sakha (Yakutia)]. Collection of scientific papers "Actual problems of emergency medical care". Yakutsk, 2003:3-5. [Article in Russian]. 6. Health personnel resources of the Republic of Sakha (Yakutia) for 2014-2016: Stat. sat / GBU ARMIES MOH Sakha (Yakutia). Yakutsk; 2017. [In Russian].

7. Golovina SM, Rogovina AG. [Features of the health of the population of the Northern territories of the Russian Federation]. Problemy Sotsialnoi Gigieny,Zdravookhraneniya, i Istorii Meditsiny. 2008;4:3-5. [Article in Russian]. 